\title{
Analysis and Simulation of Mesoscale Convective Systems Accompanying Heavy Rainfall: The Goyang Case
}

\author{
Hyun-Young Choi ${ }^{1}$, Ji-Hyun $\mathrm{Ha}^{1}$, Dong-Kyou Lee ${ }^{1}$ and Ying-Hwa Kuo ${ }^{2}$ \\ ${ }^{1}$ Atmospheric Sciences Program, School of Earth and Environmental Sciences, Seoul National University, Seoul, Korea \\ ${ }^{2}$ National Center for Atmospheric Research, Boulder, Colorado, U. S. A.
}

(Manuscript received 24 December 2010; revised 6 February 2011; accepted 8 February 2011)

(C) The Korean Meteorological Society and Springer 2011

\begin{abstract}
We investigated a torrential rainfall case with a daily rainfall amount of $379 \mathrm{~mm}$ and a maximum hourly rain rate of $77.5 \mathrm{~mm}$ that took place on 12 July 2006 at Goyang in the middlewestern part of the Korean Peninsula. The heavy rainfall was responsible for flash flooding and was highly localized. High-resolution Doppler radar data from 5 radar sites located over central Korea were analyzed. Numerical simulations using the Weather Research and Forecasting (WRF) model were also performed to complement the high-resolution observations and to further investigate the thermodynamic structure and development of the convective system. The grid nudging method using the Global Final (FNL) Analyses data was applied to the coarse model domain $(30 \mathrm{~km})$ in order to provide a more realistic and desirable initial and boundary conditions for the nested model domains $(10 \mathrm{~km}, 3.3 \mathrm{~km})$. The mesoscale convective system (MCS) which caused flash flooding was initiated by the strong low level jet (LLJ) at the frontal region of high equivalent potential temperature $\left(\theta_{\mathrm{e}}\right)$ near the west coast over the Yellow Sea. The ascending of the warm and moist air was induced dynamically by the LLJ. The convective cells were triggered by small thermal perturbations and abruptly developed by the warm $\theta_{\mathrm{e}}$ inflow. Within the MCS, several convective cells responsible for the rainfall peak at Goyang simultaneously developed with neighboring cells and interacted with each other. Moist absolutely unstable layers (MAULs) were seen at the lower troposphere with the very moist environment adding the instability for the development of the MCS.
\end{abstract}

Key words: Heavy rainfall, Mesoscale Convective Systems (MCSs), Doppler Radar data, the Weather Research and Forecasting (WRF) model

\section{Introduction}

In the Korean Peninsula, the heavy rainfall of the summer monsoon season frequently results from mesoscale convective systems (MCSs) accompanying monsoon fronts and typhoons. The MCSs occasionally bring sudden and excessive amounts of precipitation locally causing losses of lives and extensive property damages. Heavy rainfall is one of the main types of natural disasters in Korea. According to the 10-year statistics (20002009), the damage to properties caused by heavy rainfall

Corresponding Author: Prof. Dong-Kyou Lee, Atmospheric Sciences Program, School of Earth and Environmental Sciences, Seoul National University, 599 Gwanak-ro, Gwanak-gu, Seoul 151-747, Korea.

E-mail: dklee@snu.ac.kr approximately equals 0.7 billion US dollars and $61 \%$ of the total damage to properties by natural disasters (National Emergency Management Agency, 2009). Loss of life and property damage has increased yearly owing to the development of a socio-economy and the increases in the population. Lee et al. (1998) showed that heavy rainfall events related to MCSs occur under certain synoptic-scale environmental conditions such as a surface frontal system accompanying an upper-level trough during the Changma period or strong instability in the vicinity of the subtropical Pacific high in the post-Changma period.

To better investigate various characteristics of MCSs, highresolution observational data such as Doppler radar data are used in many studies. For instances, Blustein and Jain (1985) studied the type of a precipitation band, such as a squall line, using the radar data. Kim and Lee (2006) investigated the characteristics of the MCSs occurring over the Korean Peninsula using single Doppler radar data and showed that the evolution process of the system is especially affected by topography; a feature that differs from previous studies over North America. However, Rinehart (1997) pointed out that single radar was not adequate in investigating the entire MCS, and recommended combined data from more than one radar data to cover entire events. In this context, Gao et al. (1999) proposed a variation method for the analysis of three-dimensional wind fields from two Doppler radars in order to gain a more complete understanding. Park and Lee (2009) recently developed a composite radar data algorithm which combines 19 Doppler radars in the Korean Peninsula.

Many numerical studies have been performed to add to the insufficient observational data for identifying MCSs (e.g., Evans and Doswell III, 2001). Schumacher and Johnson (2006) successively simulated a MCS using the advanced research weather research and forecasting (WRF-ARW) model, and showed that deep convection could repeatedly develop without a well-defined outflow boundary. Parker (2007) performed real and ideal simulations to investigate basic kinematics and precipitation features of parallel stratiform convective systems. In some numerical studies, it was also shown that the initiation of mesoscale systems in real cases was difficult to simulate well because initial and boundary data were not sufficiently enforced to identify storms. Therefore, many studies have suggested that data assimilation is a useful tool in order to improve the initial conditions for 
simulations (e.g., Wee, 1999; Liu et al., 2005; Yu, 2007).

Previous studies have explained the developing mechanism of MCS in summer time using surface-based buoyancy, which is frequently represented by Convective Available Potential Energy (CAPE) (e.g., Bryan and Fritsch, 2000; Bryan, 2005). However, over the Korean Peninsula, MCS were frequently observed under highly baroclinic environments without large CAPE. Therefore there is a need to understand and investigate the development of MCSs over the Korean Peninsula. With this motivation, we examined the characteristics of a MCS which caused torrential rainfall over the central Korean Peninsula.

This paper is organized as follows. A description of the data used is given in section 2, and the MCS case and relative synoptic environment are presented in section 3. In section 4, the structure and development of the MCS are investigated using observational data including high-resolution Doppler radar data. To complement the lack of observations, numerical simulations using the WRF model were performed and the results are discussed in section 5. Finally, the conclusions and discussion are provided in section 6 .

\section{Data}

In order to investigate the characteristics of MCS in terms of the three dimensional distribution of reflectivity and wind, the composite Doppler radar data sets were used. The Doppler radar data were retrieved from the 5 radar sites of Baengnyeong (RBRI), Gwangduck (RGDK), and Incheon (RIIA) that are operated by the Korea Meteorological Administration (KMA), and Wonju (RWNJ) and Pyeongtaek radars (RKSG) respectively operated by the Republic of Korea Air Force (ROKAF) and the US Air Force (UAF) (Fig. 1). NCAR/SPRINT (National Center for Atmospheric Research / Sorted Position Radar INTerpolation) and CEDRIC (Custom Editing and Display of Reduced Information in Cartesian Space) were adapted to interpolate and
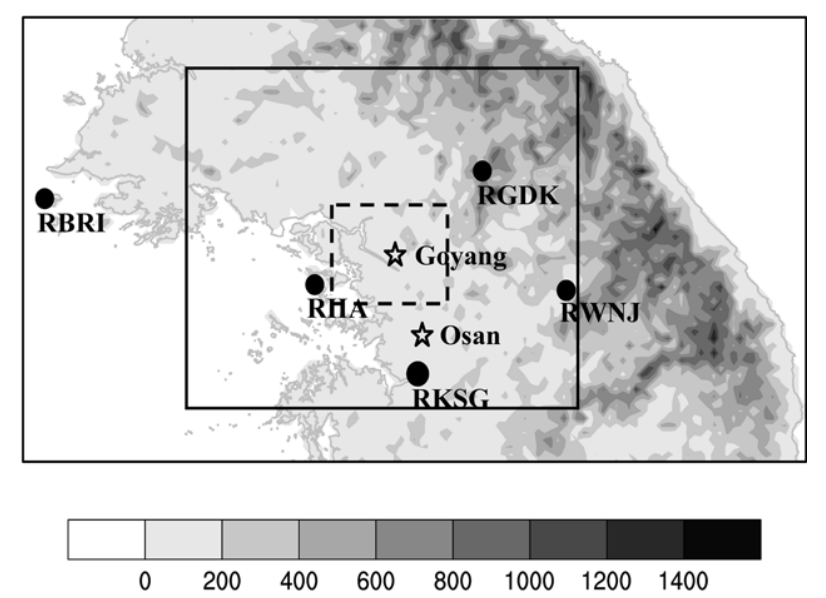

Fig. 1. Topography ( $m$, shaded) and locations of the utilized five radar sites (RBRI, RIIA, RGDK, RKSG, RWNJ) over the Central Korean Peninsula. The star mark denotes the location of Goyang and Osan, and the solid square denotes the synthesized domain. The dashed box denotes the analyzed area in Fig. 6. visualize the radar data. Alias correction of observed radial velocity data was carried out to ensure spatial continuity, and abnormal values compared with area-averaged values were eliminated as noise resulting from low PRF (Pulse Repetition Frequency) (Park and Lee, 2009). The analyzed data covered an area of $250 \mathrm{~km} \times 200 \mathrm{~km}$ with $1 \mathrm{~km}$ horizontal resolution and $0.5 \mathrm{~km}$ vertical resolution from $1.5 \mathrm{~km}$ to $10.0 \mathrm{~km}$ above sea level. It is hard to retrieve information below $1.5 \mathrm{~km}$ using Doppler radar data due to the presence of complicated topography over the Korean Peninsula. Thus the observed structure of the lower troposphere such as the planetary boundary layer (PBL) is analyzed using the radiosonde data at Osan which is located $60 \mathrm{~km}$ south of the location of the maximum rainfall (Fig. 1).

Within the analyzed domain, the radar data were composed with a 10-minute temporal resolution. In order to analyze the synoptic environments, the 6-hourly Global Final (FNL) analyses on $1.0^{\circ} \times 1.0^{\circ}$ grids from the National Center for Environmental Prediction (NCEP) were used. The visual and infrared satellite images produced by the Multifunctional Transport Satellite (MTSAT) of Japan were also used to examine the initiation, development, and dissipation of MCSs tracing the propagation of systems. The rain gauge data from the Automatic Weather Stations (AWS) of KMA, which have a 1-minute time update resolution, were analyzed to investigate the time series of rainfall, the amount of daily rainfall, and specific variations of surface temperature.

\section{Synoptic environments of the heavy rainfall case}

Heavy rainfall occurred over Goyang city, in the west-central region of Korean Peninsula, on 12 July 2006. The maximum daily rainfall amount in this case was $379 \mathrm{~mm}$ with a maximum hourly rain rate of $77.5 \mathrm{~mm}$ (Fig. 2a). The intensive rainfall was greater than $200 \mathrm{~mm}$ and it was localized within a $2000 \mathrm{~km}^{2}$ area, indicating a meso- $\beta$ scale event.

The time series of the 1-hour and 15-minute rainfall amount at Goyang are shown in Figs. $2 b$ and $2 c$. In the hourly time series, the rainfall started at 1800 UTC 11 July with an hourly maximum precipitation at 2300 UTC 11 July, and a 2-hour break-off period from 0300 UTC to 0500 UTC 12 July. Subsequently, heavy rainfall with $30 \mathrm{~mm} \mathrm{~h}^{-1}$ intensity occurred again, it continued for 2 hours, and then the precipitation almost stopped. The main rainfall lasted 6 hours, from 2100 UTC 11 July to 0300 UTC 12 July. In order to examine in detail the evolution of the rainfall, we focused on the time period from 2100 UTC 11 July to 0100 UTC 12 July which was the main precipitation period. The time series show the first peak at 2215

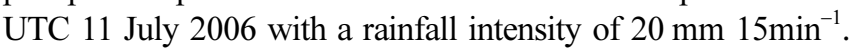
After a temporary break for a few minutes, the maximum intensity reached $32 \mathrm{~mm} 15 \mathrm{~min}^{-1}$ at 2250 UTC 11 July. In the time series, the third peak was maintained with rainfall intensity

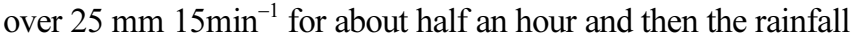
dissipated.

The MCS which caused the heavy precipitation initiated over 

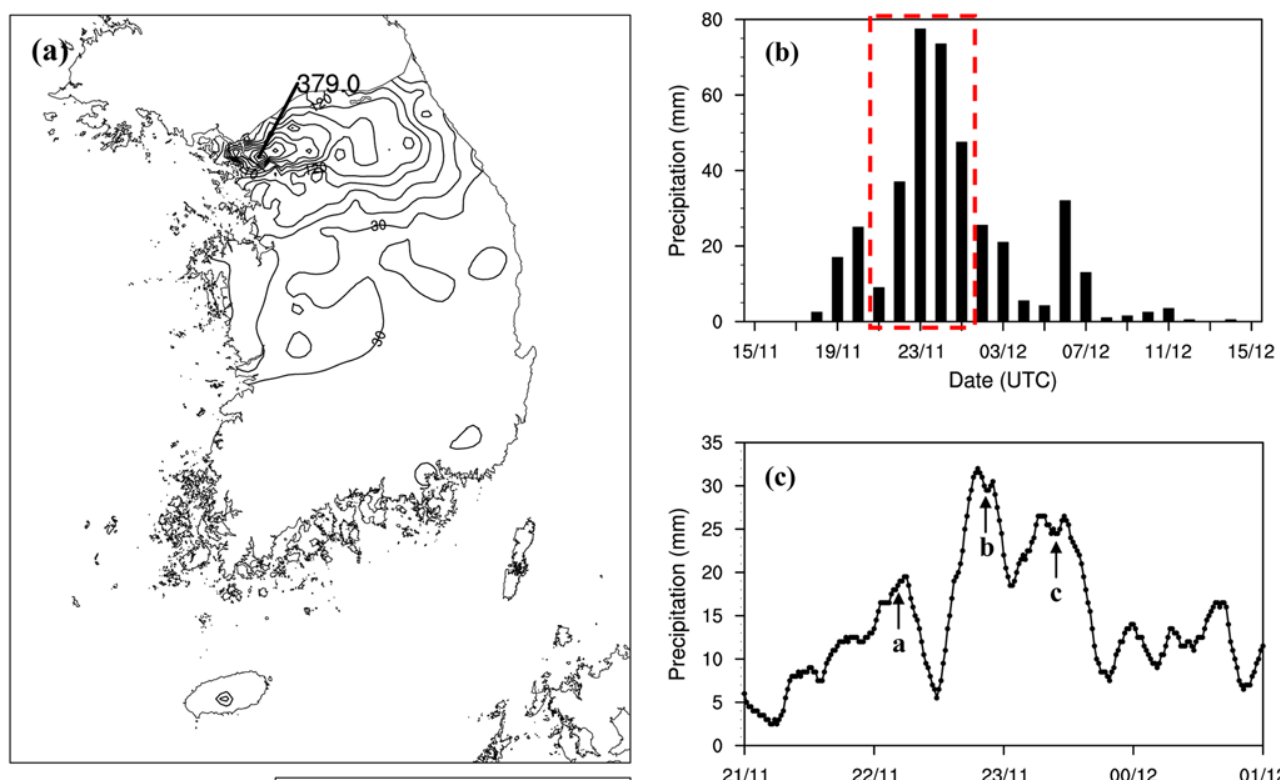

CONTOUR FROM 30 TO 360 BY 30

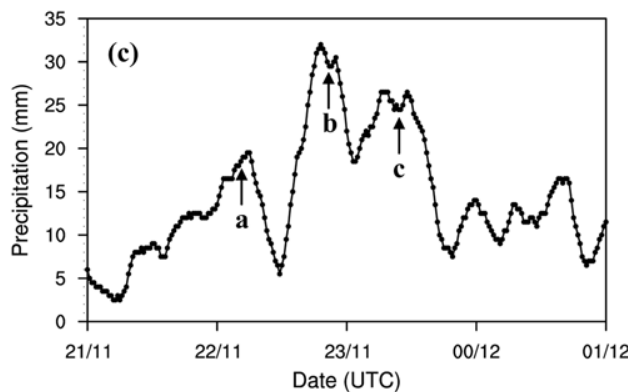

Fig. 2. (a) The 24-hour accumulated rainfall amounts observed by AWS over the central Korean Peninsula from 1500 UTC 11 July to 1500 UTC 12 July 2006. The time series of (b) hourly rainfall from 1500 UTC 11 July to 1500 UTC 12 July 2006 and (c) 15-min accumulated rainfall amount from 2100 UTC 11 July to 0100 UTC 12 July 2006 which was the most intensive precipitation period at Goyang (red dotted box in (b)).

(a) 2000 UTC July 11

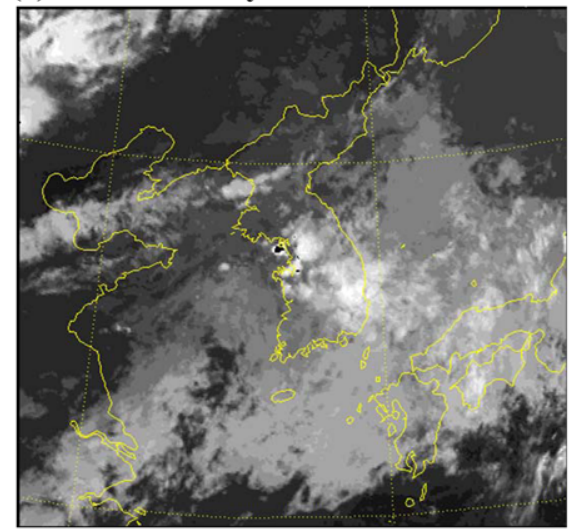

(c) 2200 UTC July 11

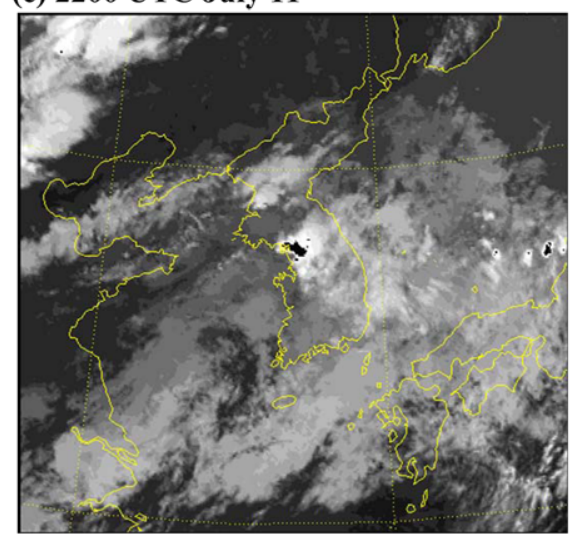

\section{(b) 2100 UTC July 11}

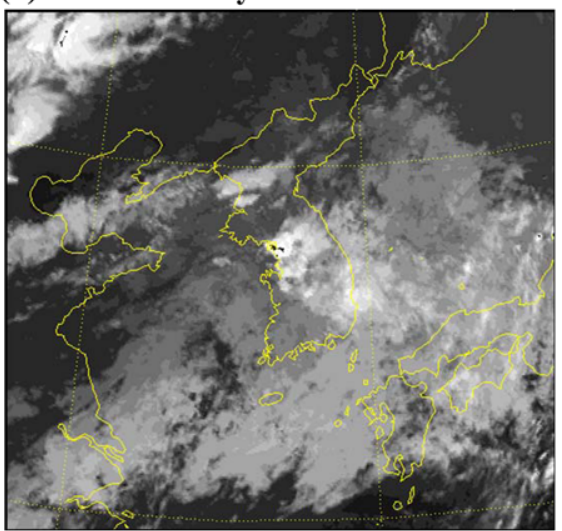

(d) 2300 UTC July 11

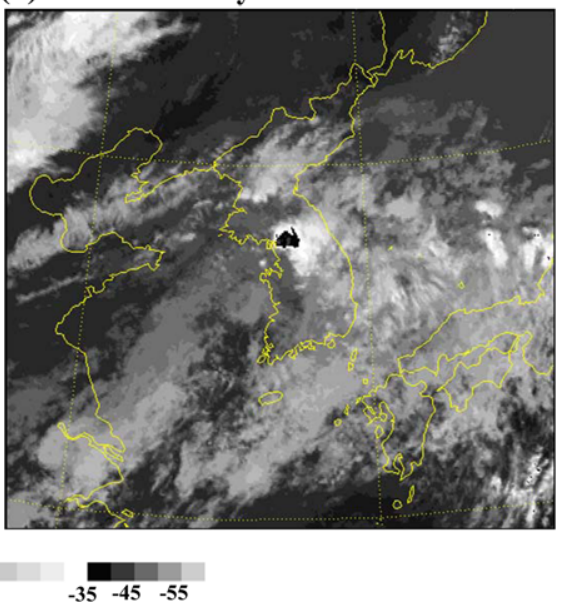

Fig. 3. MTSAT IR satellite images from 2000 UTC to 2300 UTC 11 July 2006 with 1-h intervals. The area of cloud top temperature that is lower than $-35^{\circ} \mathrm{C}$ is emphasized. 
the sea near the west coast of the central Korean Peninsula at 2000 UTC (Fig. 3a). MTSAT satellite IR image clearly shows the development of the MCS affecting the heavy rainfall at Goyang. The convective cell moved inland and was organized as the MCS extended eastward at 2100 UTC (Fig. 3b). It stagnated over the Goyang region for about 4 hours from 2100 UTC 11 July to 0100 UTC 12 July, and the mature feature of the convection was noted at 2300 UTC (Figs. 3c and 3d). The topography along the west-east direction around Goyang surrounds the eastern side with mountains whereas the western side is exposed. In this study, the topography seemed to prevent con- vective storms from moving eastward, which restrained the storms to the heavy rainfall region (Fig. 1). At 2300 UTC, the deep and intensive convection caused the torrential rainfall. After 0100 UTC 12 July, the MCS decayed and moved eastward.

Figure 4 shows the $200 \mathrm{hPa}, 500 \mathrm{hPa}, 850 \mathrm{hPa}$, and the surface weather charts at 1200 UTC 11 July 2006, 6 hours before the rainfall began. At the $200 \mathrm{hPa}$ level (Fig. 4a), an upper level jet with a speed of about $35 \mathrm{~m} \mathrm{~s}^{-1}$ was located at the north of the Korean Peninsula. At the $500 \mathrm{hPa}$, accompanying a trough near northeastern Manchuria, a low pressure system developed over Northeastern Mongolia (Fig. 4b). At $850 \mathrm{hPa}$, a deep (a) 1200 UTC July 11
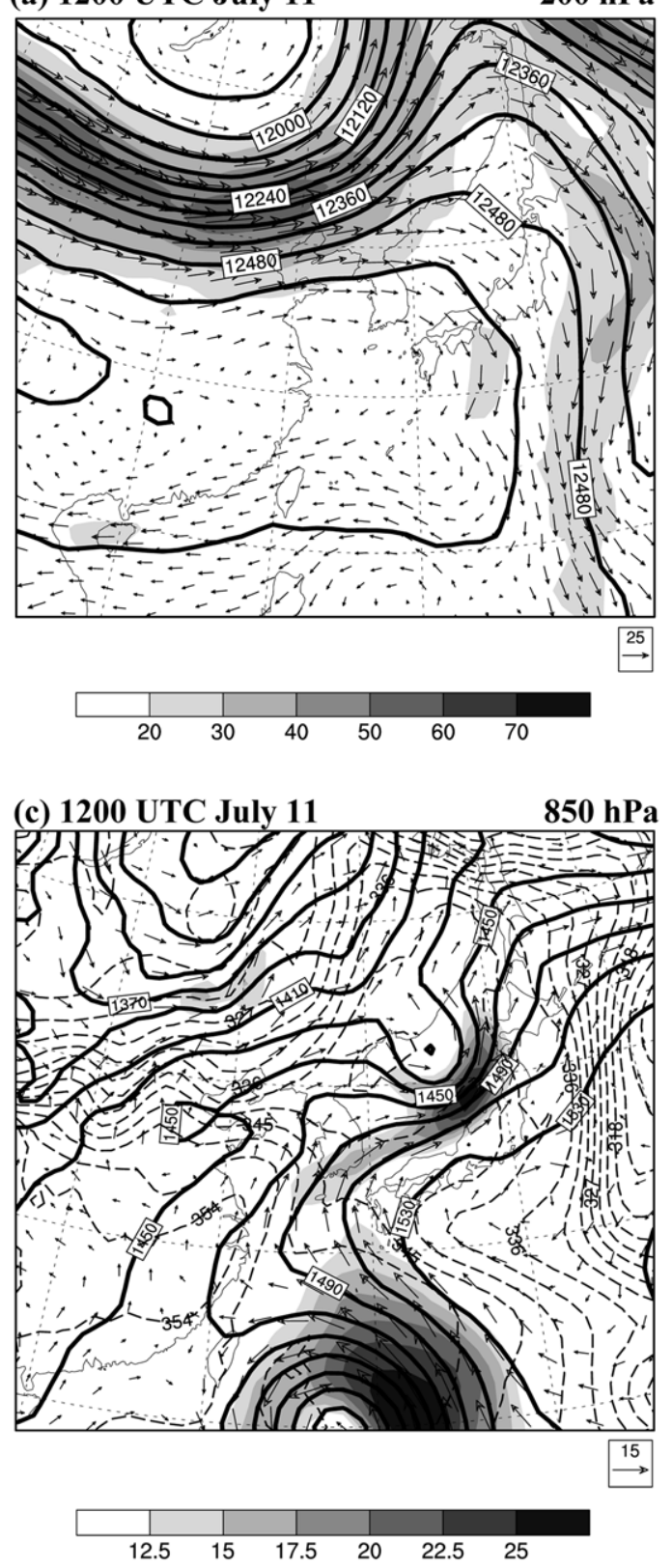
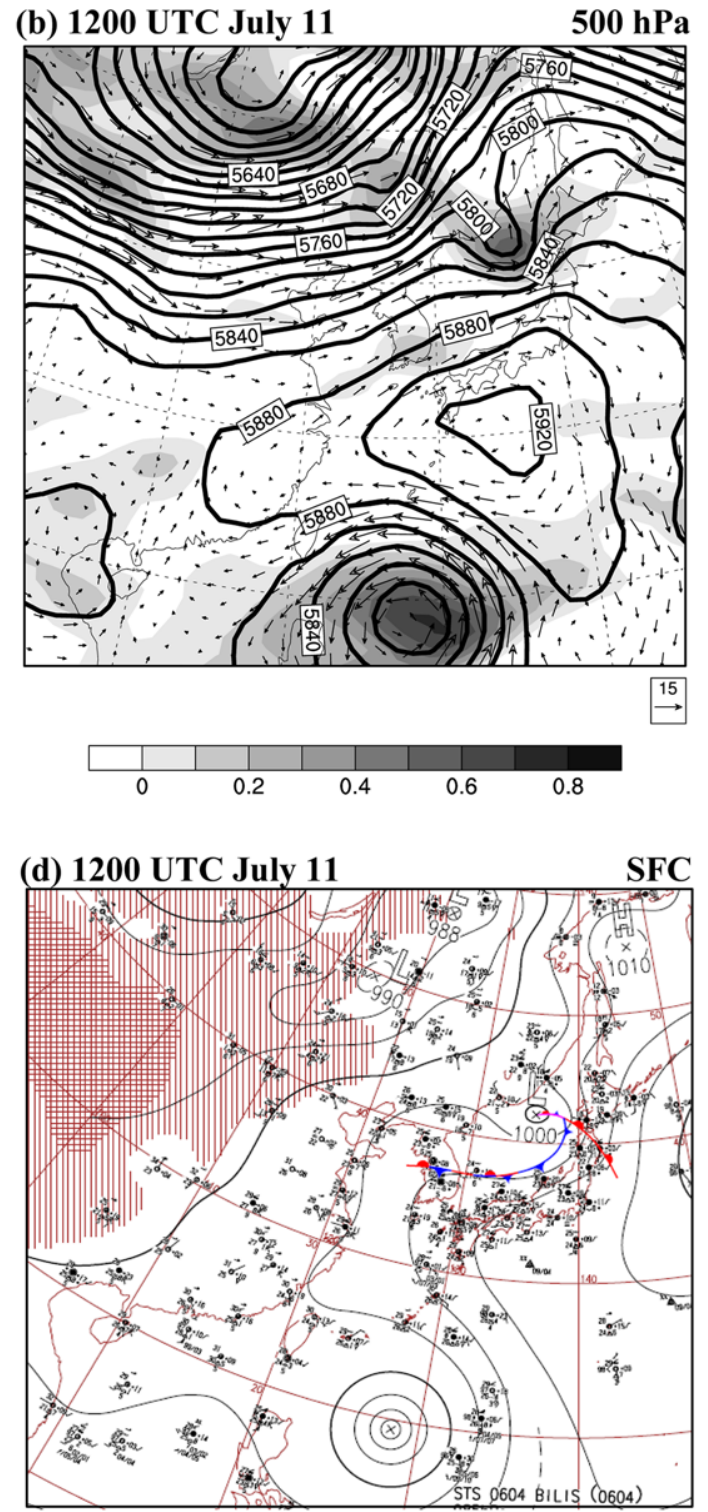

Fig. 4. (a) 200, (b) 500, (c) $850 \mathrm{hPa}$ and (d) surface weather chart at 1200 UTC 11 July 2006. Shaded area (a) strong wind speed (>25 m s${ }^{-1}$ ) at 200 $\mathrm{hPa}$, (b) absolute vorticity at $500 \mathrm{hPa}$, (c) wind speed $\left(>12 \mathrm{~m} \mathrm{~s}^{-1}\right)$ at $850 \mathrm{hPa}$. Solid lines denote the geopotential height (gpm). Dotted lines denote temperature $\left({ }^{\circ} \mathrm{C}\right)$, except for equivalent potential temperature $(\mathrm{K})$ at $850 \mathrm{hPa}$. 
thermal trough that originated from northeastern Manchuria extended toward the Korean Peninsula. The northeastward moving typhoon passed through the westward extended Pacific subtropical high, and pushed the subtropical high farther north thus taking moisture from the ocean. Consequently, the enhanced pressure gradient between the continental low pressure and the subtropical high intensified the southeasterly flows as low-level jets (LLJ) which conveyed warm moist air to the Korean peninsula. Hence, the area of equivalent potential temperature over $342 \mathrm{~K}$ extended to the heavy rainfall region. Accordingly, the relatively cold and dry continental air mass associated with the trough and the warm and moist maritime air mass conveyed by the subtropical high pressure extended toward Japan and southern China, and they developed a thermal gradient and baroclinicity near the western part of Korean Peninsula (Fig. 4c). At the surface, the Korean Peninsula was on the edge of the North Pacific high pressure system. Over the central Korean Peninsula, the Changma front extended from a low-pressure center located in the northern East Sea (Fig. 4d).

At 0000 UTC 12 July, the time of maximum rainfall intensity,
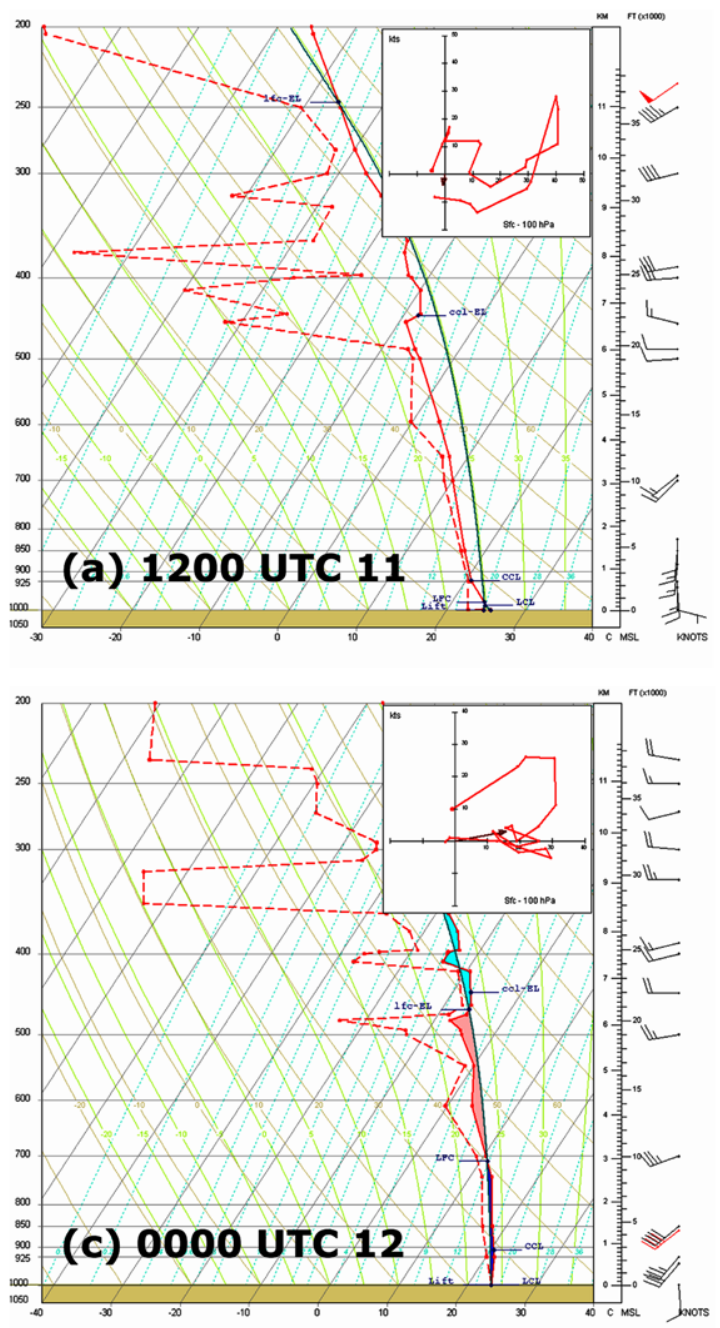

Fig. 5. The sounding data and hodograghs observed by Osan rawinsonde at (a) 1200 UTC , (b) 1800 UTC 11 July and (c) 0000 UTC 12 July 2006. The shaded area with red denotes the LFC based CAPE and that with pink denotes CAPE. The blue area denotes CIN.

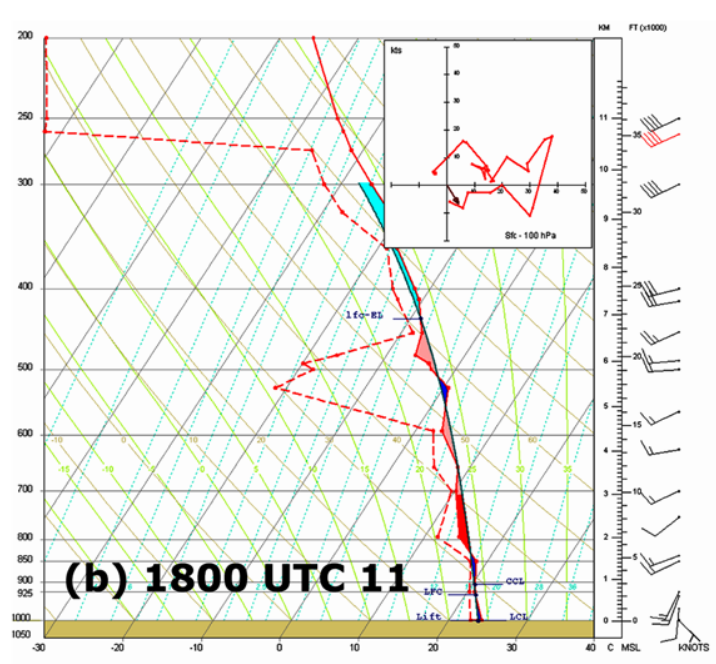

there were no remarkable changes at $200 \mathrm{hPa}$ and $500 \mathrm{hPa}$ weather charts. On the other hand, in the low-level atmosphere, the northward moving typhoon pushed the high pressure system further north and intensified the pressure gradient enhancing moisture advection toward the central Korean Peninsula along the LLJ.

The skew T - $\log \mathrm{P}$ charts and hodographs at Osan are shown in Fig. 5. Osan is located approximately $60 \mathrm{~km}$ south of Goyang (Fig. 1). Since the lower atmosphere was very moist during the entire target period, the lapse rate of temperature was similar with the moist adiabatic lapse rate. It means that the lower troposphere was statically neutral or slightly unstable due to air saturation. The lifting condensation level (LCL) and level of free convection (LFC) appeared near the surface. On the other hand, dry layers above $500 \mathrm{hPa}$ level at 1200 UTC 11 July descended down to $600 \mathrm{hPa}$ level after 6 hours. The dry layer was mainly constrained between $450 \mathrm{hPa}$ and $550 \mathrm{hPa}$ levels causing a strong vertical dry-moist contrast. At 0000 UTC 12 July, just after the target MCS passed over Goyang, the dry layer became weaker compared to previous times. It should be noted 
that the convective available potential energy (CAPE) was not as large as the typical values at Osan. In this case, the CAPE was $788 \mathrm{~J} \mathrm{~kg}^{-1}$ at $1200 \mathrm{UTC} 11,123 \mathrm{~J} \mathrm{~kg}^{-1}$ at $1800 \mathrm{UTC} 11$, and 136 $\mathrm{J} \mathrm{kg}^{-1}$ at $0000 \mathrm{UTC} 12$ which means that the instability was not solely due to surface-based buoyancy. The wind direction in the lower troposphere had changed from southerly at 1200 UTC 11 to southwesterly at 0000 UTC 12 . Furthermore, the wind speed at $850 \mathrm{hPa}$ level abruptly increased up to $20 \mathrm{~m} \mathrm{~s}^{-1}$ at $0000 \mathrm{UTC}$ 12 , which can be considered as a low level jet (LLJ). The hodographs during the target period showed that there was veering in the lower troposphere, that is, warm advection was prominent from the southern or southwestern region.
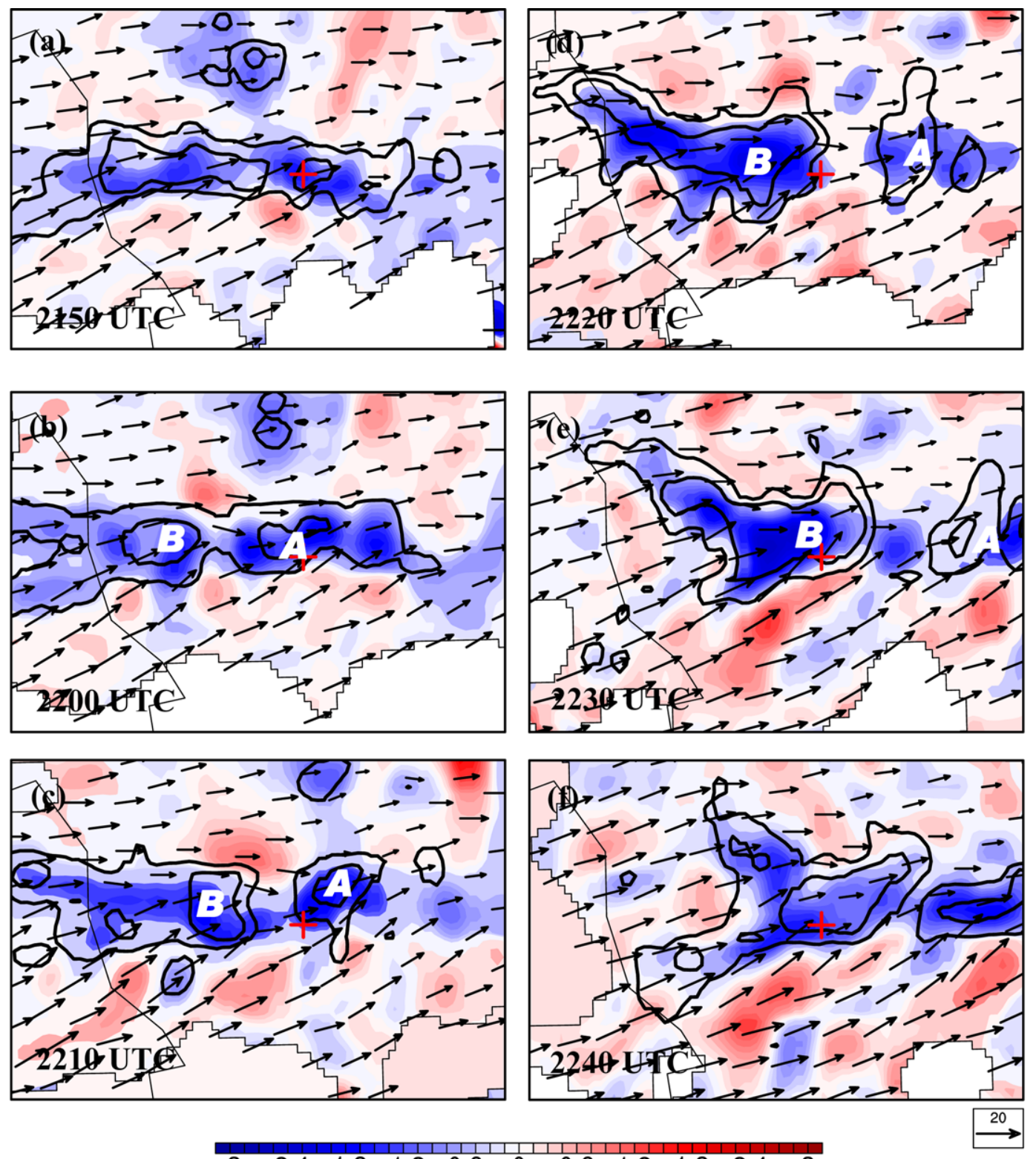

$\begin{array}{llllllllllll}-3 & -2.4 & -1.8 & -1.2 & -0.6 & 0 & 0.6 & 1.2 & 1.8 & 2.4 & 3\end{array}$

Fig. 6. The radar-observed divergence field (shaded) and reflectivity (contour) at the $3 \mathrm{~km}$ height from 2150 UTC to 2240 UTC $11 \mathrm{July} 2006 \mathrm{with}$ 10 -minute intervals. The red crosses denote the location of Goyang. 
the land near the west coast at 2150 UTC, the linear convective system was further developed because the southwesterly wind at the southern part of the convergence area was stronger than the westerly wind at its northern part, and thus the horizontal wind shear enhanced the convergence intensity (Fig. 6a). The orientation of the MCS took a west-east direction and the MCS moved eastward. The meridional scale of the convective area over $39 \mathrm{dBZ}$ was about $10 \mathrm{~km}$, while the zonal scale was approximately $50 \mathrm{~km}$. The propagation of the convective system in this study showed the evolution of a parallel stratiform (PS) linear MCS according to the taxonomy of Parker and Johnson (2000). The parallel stratiform type was characterized by a convective line with parallel precipitation and back-building of a convective cell.

It is notable that a divergence appeared in the middle of the convergence area at 2200 UTC, and the convective cell separated into two parts at $2210 \mathrm{UTC}$, which we identified as cell A and B in chronological order (Figs. 6b and 6c). The antecedent convective cell A moved eastward faster than cell $\mathrm{B}$ behind the cell $\mathrm{A}$, and then the two convective systems were further segregated. The passing of the cell A is well-matched with the first peak of every-minute rainfall observation (Fig. 2c). Owing to the notably strong local divergence between convective cells $\mathrm{A}$ and $\mathrm{B}$, the precipitation had a break-off at Goyang for about 10 minutes around 2215 UTC. The strong local divergence between cells A and $\mathrm{B}$ seemed to inhibit the propagation of cell $\mathrm{B}$ while the convergence inside each cell was strengthened. Consequently, the reflectivity of cell B became stronger during 2220 UTC and 2230 UTC and then the convective cell B developed further as the convergence in the vicinity of the storm enhanced (Figs. $6 \mathrm{~d}$ and 6e). The convective cell $\mathrm{B}$ produced the most intensive rainfall at 2240 UTC which corresponds to the second rainfall peak (Fig. 6f).

In order to investigate the separation of the convergence line to develop the cell $\mathrm{B}$, we examine the time variation of the vertical cross section of reflectivity and wind vectors along the system propagation in a direction parallel with lines of latitude (Fig. 7). At 2200 UTC, mean upward flow inside cell A tilted eastward with height as the flow ascended along the outflow boundary of the antecedent convection (Fig. 7a). At 2210 UTC, as cell A propagated to the east with flash precipitation, a downward motion appeared right behind the maximum reflectivity of cell A (Fig. 7b). The downward motion brought cold and dry air from the upper troposphere to surface and enhanced the convective instability at the leading edge of the cell B. As a result, evaporation at the leading edge of the cell $\mathrm{B}$ might have increased and the downward motion of cooled air from evaporation helped to sustain steady upward motion. At 2220-2230 UTC, cell B propagated to the east rather slowly, and then cells A and B completely separated (Figs. 7c and 7d). The upward motion at the leading edge of cell B was relatively more upright than that in cell A. It might be inferred that both cells A and B developed simultaneously, as many multicell-type convective storms do. At 2240 UTC, cell B reached its mature stage (Fig. $7 \mathrm{e})$. It depicts that the convective core of the cell reached about
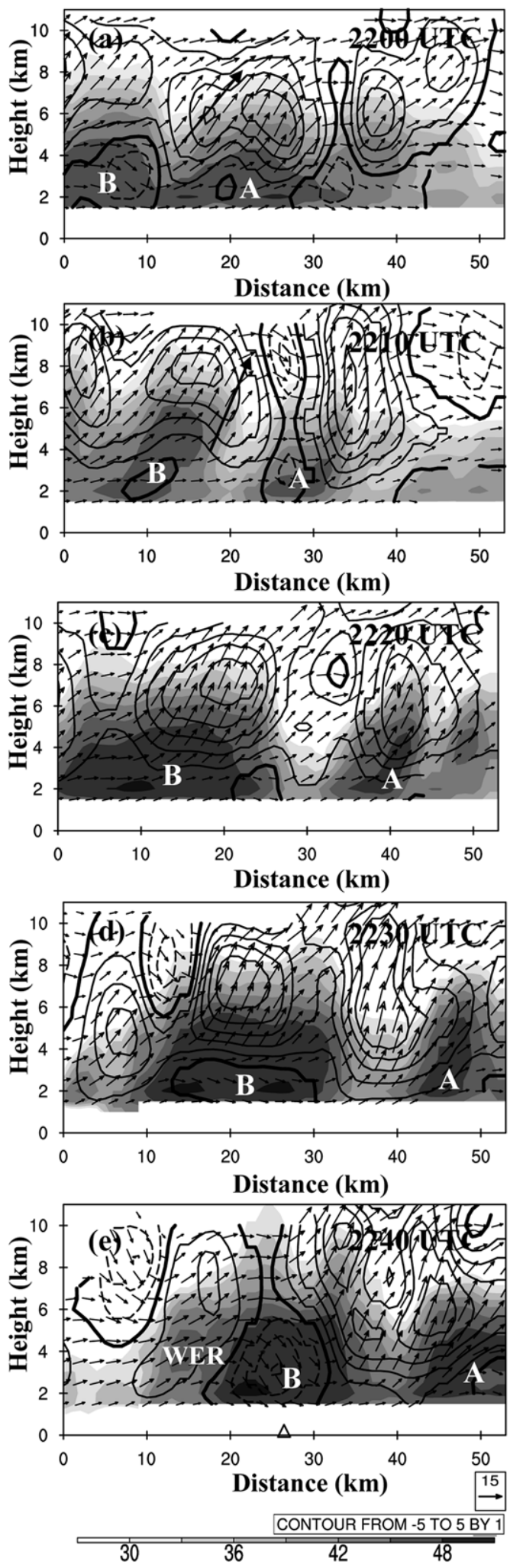

Fig. 7. The vertical cross section of radar-observed reflectivity (dBZ, shaded), vertical velocity $\left(\mathrm{m} \mathrm{s}^{-1}\right.$, positive (negative) values solid (dashed)) and wind fields $\left(\mathrm{m} \mathrm{s}^{-1}\right)$ along the system propagation from 2200 UTC to 2240 UTC 11 July 2006 with 10 minute intervals. Thick black arrows denote stream lines inside storms. The 'WER' remark denotes a weak echo region. 
$10 \mathrm{~km}$ height and a strong downward motion appeared at the center of the convective cell. The well-known indicators of strong updraft in a developing storm: continuous rear-inflow and weak echo region (WER) were found at the rear of the cell. Local convergence in the middle troposphere and local divergence in the lower troposphere at the convective core of cell B were also observed like general convective cells in their mature stage.

\section{Numerical simulation results}

\section{a. Simulation design}

In order to investigate in detail the features of the structure of the MCS, in addition to the analysis of the observational data, we conducted a numerical simulation using the WRF model version 3.1 (Skamarock et al., 2005). We performed the simulations using a threefold one-way nesting system with three model domains of 30-, 10-, and 3.3-km horizontal resolution (Fig. 8). The lateral boundary conditions for the outermost grid with the $30-\mathrm{km}$ horizontal resolution were provided by linear temporal interpolations of the 6-h the FNL Analyses data. The outer model domain provided the initial and boundary conditions to the nested inner finer grid model domains. The simulation on the most outer domain and two nested domain was carried out for 36, 30, and 24 hours, starting at 0000 UTC, 0600 UTC, and 1200 UTC 11 July 2006, respectively. In order to provide more realistic and desirable initial and boundary conditions for the nested domains, the grid-nudging method is applied to the simulation of the outermost grid during the entire runtime using FNL data. The simulation with the grid-nudging method improved the synoptic-scale patterns and the location of precipitation compared to the simulation without the grid-nudging method (Fig. 9).

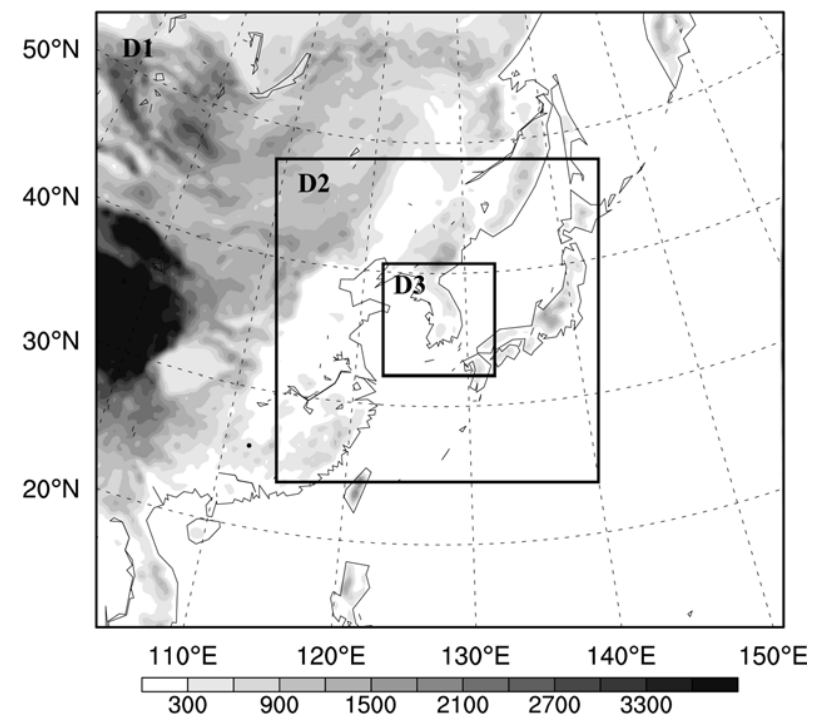

Fig. 8. Model domain area of domains 1, 2, and 3. Shading shows terrain heights over the domain.
In this study, the model included the Kain-Fritsch cumulus parameterization scheme for subgrid-scale convection (Kain and Fritsch, 1990, 1993; Kain, 2004), and the WRF single-Moment six-class (WSM6) microphysics scheme for grid-scale cloud and precipitation (Hong et al., 2004). We used the Yonsei University

(a) CTL

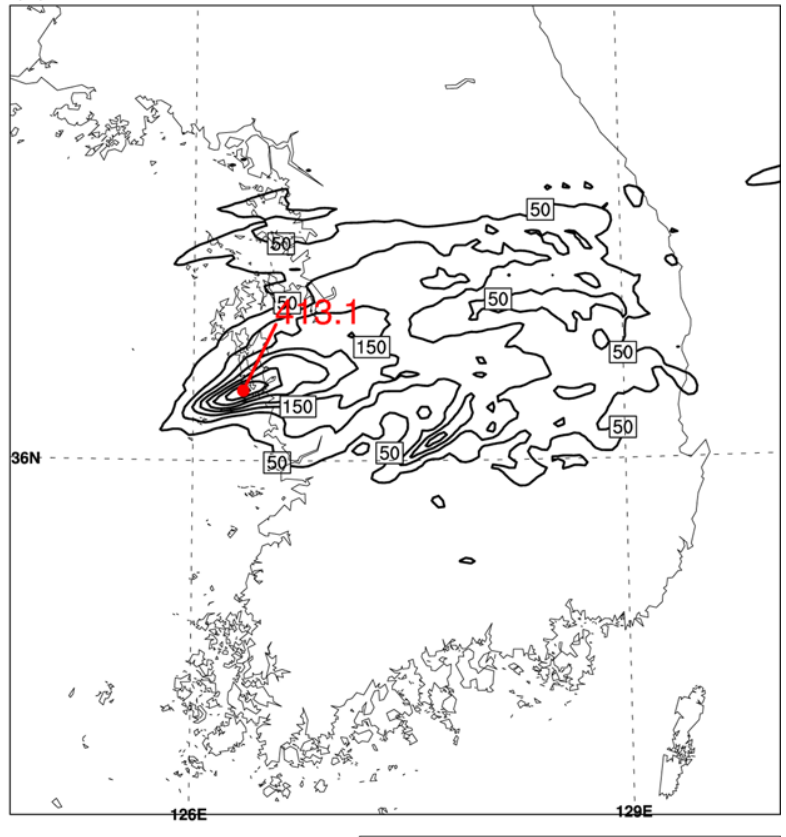

CONTOUR FROM 50 TO 400 BY 50

(b) Grid-nudging

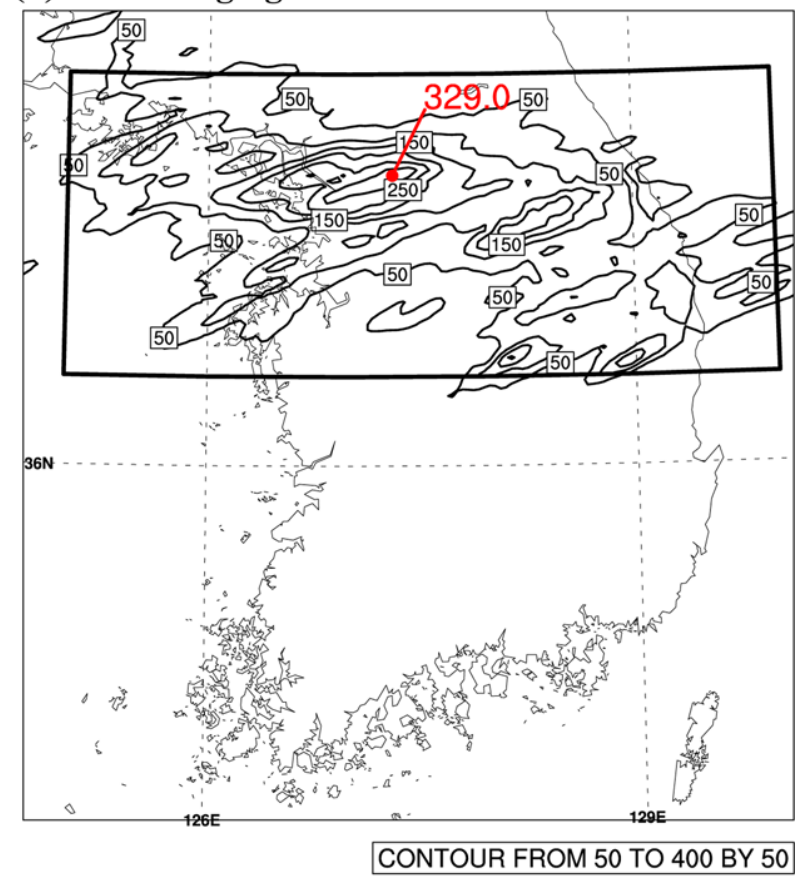

Fig. 9. Simulated 24-hour accumulated rainfall in domain 3 from (a) CTL and (b) grid-nudging experiments. The solid box in (b) denotes the analyzed area in Fig. 10. 
Table 1. Configurations of numerical model experiment using WRF model.

\begin{tabular}{cccc}
\hline & Domain 1 & Domain 2 & Domain 3 \\
\hline Horizontal Resolution & $30 \mathrm{~km}$ & $10 \mathrm{~km}$ & $3.3 \mathrm{~km}$ \\
Horizontal Dimensions & $191 \times 171$ & $265 \times 265$ & $283 \times 283$ \\
Time interval $(\Delta \mathrm{t})$ & $90 \mathrm{~s}$ & $30 \mathrm{~s}$ & $10 \mathrm{~s}$ \\
& $00 \mathrm{UTC}$ & $06 \mathrm{UTC}$ & $12 \mathrm{UTC}$ \\
Initial time & $11 \mathrm{July}$ & $11 \mathrm{July}$ & $11 \mathrm{July}$ \\
Run time & $36 \mathrm{~h}$ & $30 \mathrm{~h}$ & $24 \mathrm{~h}$ \\
Initial / Boundary & Global Final (FNL) Analyses data set \\
condition & \multicolumn{3}{c}{ WSM6 } \\
Microphysics & \multicolumn{3}{c}{ RRTM / Dudhia } \\
Radiation & \multicolumn{3}{c}{ 5-layer thermal diffusion } \\
Land surface & KSU \\
PBL & \multicolumn{3}{c}{ Kain-Fritsch } \\
CPS & \multicolumn{3}{c}{ None } \\
Data assimilation & Grid nudging \\
\hline
\end{tabular}

(YSU) scheme for the planetary boundary layer (Hong et al., 2006) and the 5-layer thermal diffusion scheme for the land surface (Dudhia, 1996). The cumulus parameterization scheme was not used in domain 3 of the $3.3 \mathrm{~km}$ grid mesh. The detailed configuration of the experiment is shown in Table 1.

\section{b. Simulated rainfall}

Prior to the investigation of the features of the MCS responsible for the heavy rainfall at Goyang, we initially evaluated the simulated rainfall. In Fig. 9 we compared the simulated daily rainfall in the $3.3 \mathrm{~km}$ grid mesh with and without the gridnudging method. In the simulation without the grid-nudging method (hereinafter, referred to as "CTL"), the distribution of the rainband shifted southward as compared to observation. The maximum rainfall also located at the western coastline of the Korean Peninsula (Fig. 9a). However, in the simulation with the grid-nudging method, the distribution of the rainfall as well as the location of the maximum rainfall was in good agreement with observation even though the amount of the simulated daily rainfall of $329 \mathrm{~mm} \mathrm{~d}^{-1}$ was underestimated relative to the observed $379 \mathrm{~mm} \mathrm{~d}^{-1}$ (Fig. 9b). In terms of the time series of hourly rainfall at Goyang, the simulation with the grid-nudging method was also greatly improved when compared with CTL, in which two major rainfall peaks were reproduced in simulation (not shown). It is notable that the amount of the maximum daily rainfall in the simulation with the grid-nudging method has about $80 \mathrm{~mm}$ less than that in CTL. Because the grid nudging enforces the model simulation with the high resolution to be adjusted to the analysis of the low resolution data, small scale features in the local convection could be diluted and lost in the simulation with the grid-nudging method more than in CTL.

In order to evaluate the evolution of the convective cells, Fig. 10 shows the reflectivity, wind vectors, and LLJ which is defined as a region with wind speed greater than $12.5 \mathrm{~m} \mathrm{~s}^{-1}$ at 2-km height from 2000-2300 UTC 11 July at 20 min intervals in the simulation with the grid-nudging method. The convective cells were generated near the west coastal region and then slowly moved eastward. It is noted that the strong reflectivity occurred along the northern edge of the LLJ which implies that interactions existed between the MCS and LLJ. From 2200-2300 UTC 11 July, a linear convective system with a strong reflectivity $(>42 \mathrm{dBZ})$ developed near Goyang and the orientation of the convective system was in the west-east direction which agreed with the observations (Fig. 6).

Because more realistic initial and boundary conditions were provided to the nested domains, the simulation with the gridnudging method can be considered reliable enough to investigate the target MCS in terms of the timing and location of the rainfall. As mentioned in the synoptic environment, the location and strength of the typhoon and the Western North Pacific high, and the resultant low-level jet were an important synoptic feature for the development of the heavy rainfall. Figure 11 shows the difference fields of geopotential heights at $700 \mathrm{hPa}$ and wind speeds at $850 \mathrm{hPa}$ between the CTL and the grid-nudging experiments in the coarsest horizontal resolution. The Western North Pacific high over the western boundary region in the domain was increased, indicating that the sub-tropical high was extended to the north in the grid-nudging experiment. The wind speed over the central Korean Peninsula was also increased due to the extended high pressure system and the enhanced typhoon. These synoptic corrections in the grid-nudging experiment remarkably improved heavy rainfall simulation.

\section{c. The structure of MCSS}

Figure 12 shows $850 \mathrm{hPa}$ equivalent potential temperature and vertical velocity at 2000 UTC in the simulation with the grid-nudging. At the time, according to the satellite and radar observations (Figs. 3 and 6), the target MCS abruptly initiated at the coastal area of the central Korean Peninsula. In the simulation, the initiation of convection near the west coastal region was depicted with a steep equivalent potential temperature $\left(\theta_{\mathrm{e}}\right)$ gradient (Fig. 12a). It was due to the contrast between the relatively cold and dry air in the north and the moist and warm air by the low-level jet in the southwest. There were lots of thermal perturbations around the region of high $\theta_{\mathrm{e}}$ inflow boundary, which indicated that the convective region initiated because of a large $\theta_{\mathrm{e}}$ gradient. Many upward motion cores simultaneously developed along these perturbations (Fig. 12b). These features indicated that the steep equivalent potential temperature contrast and its derived perturbations provided a favorable condition to the initiation of the MCS.

Bryan and Fritsch (2000) addressed the above condition as a desirable environment to develop MCSs within moist absolutely unstable layers (MAULs). Moist absolute instability exists when the atmosphere creates and maintains a saturated environment with a lapse rate $\left(\gamma_{\mathrm{s}}\right)$ greater than the moist-adiabatic lapse rate $\left(\Gamma_{\mathrm{s}}\right)$, that is $\gamma_{\mathrm{s}}>\Gamma_{\mathrm{s}}$. All parcels in the saturated layer are unstable 

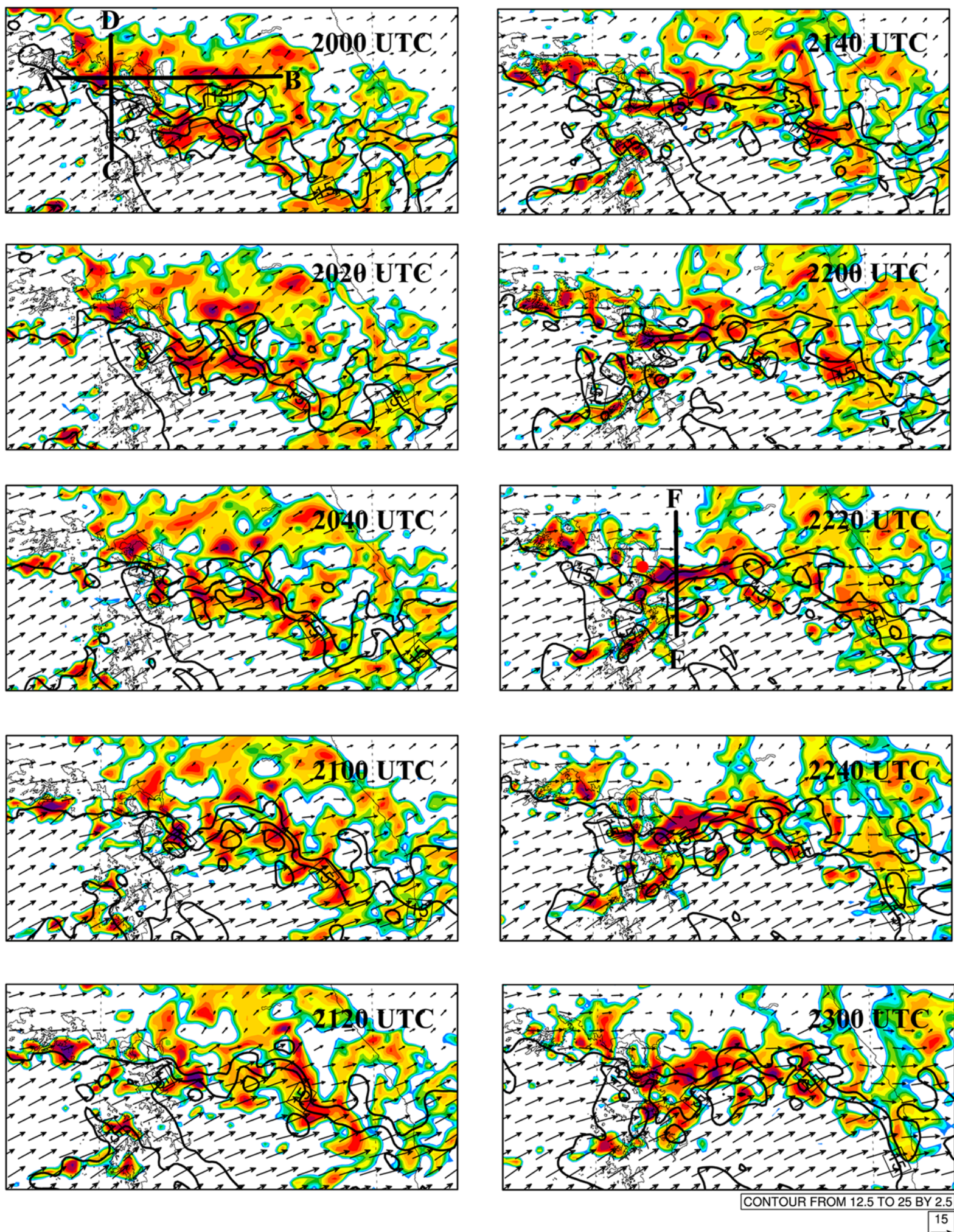

\begin{tabular}{lll|l|l|l|l}
15 & 21 & 27 & 33 & 39 & 45
\end{tabular}

Fig. 10. Simulated reflectivity (dBZ, shaded), wind speed $\left(\mathrm{m} \mathrm{s}^{-1}\right.$, contour) and wind vectors $\left(\mathrm{m} \mathrm{s}^{-1}\right)$ at the 2 km height in the grid-nudging experiment from 2000 UTC 11 July to 2300 UTC 11 July at 20 min intervals. 
(a) $700 \mathrm{hPa}$ geopotential height and winds

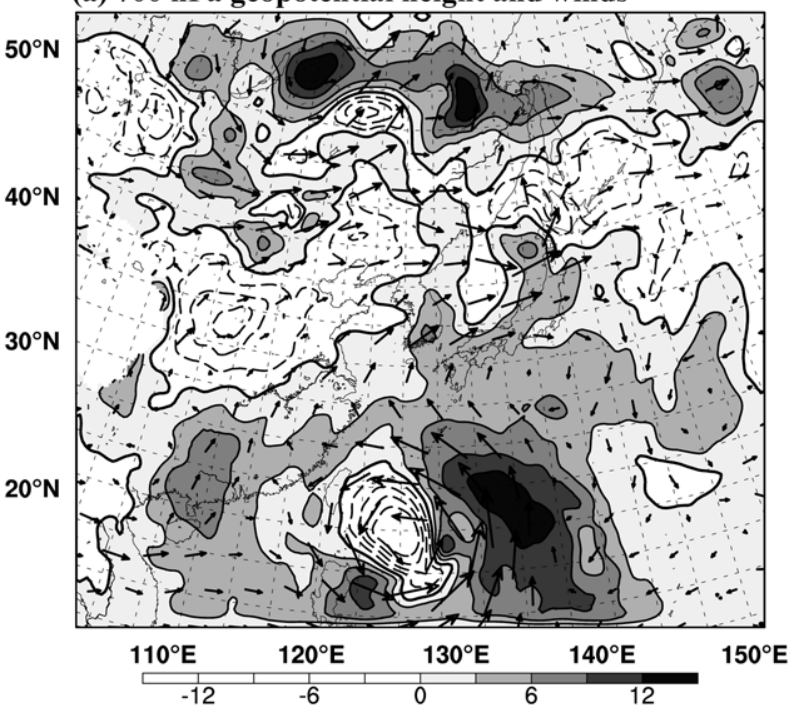

(b) $850 \mathrm{hPa}$ wind speed and winds

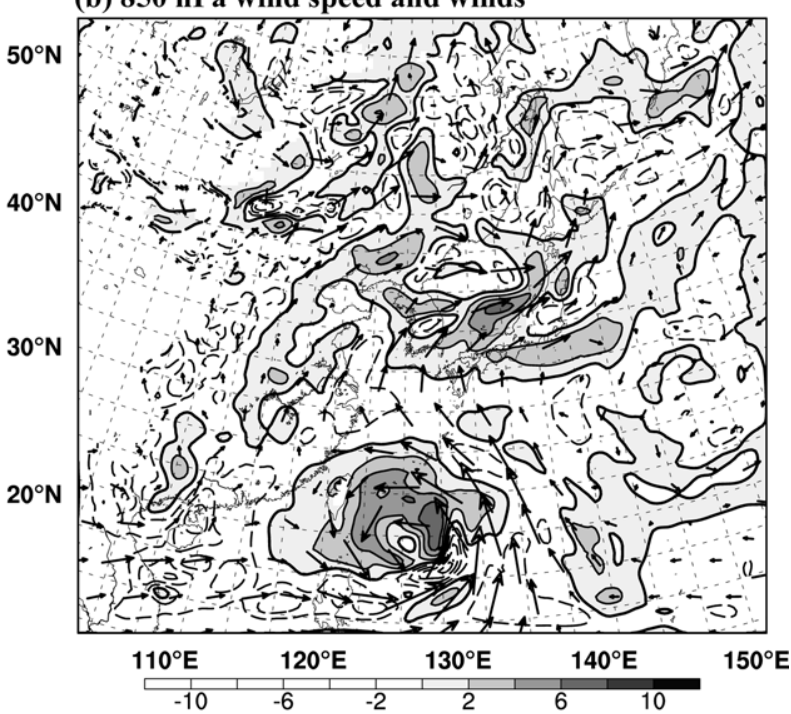

Fig. 11. Difference fields of (a) geopotential height at $700 \mathrm{hPa}$ (positive areas are shaded) and (b) wind speed at $850 \mathrm{hPa}$ (positive areas are shaded) in the grid-nudging experiment from that in the CTL experiment at 1800 UTC 11 July 2006.

at any displacement, thus, the layer inherently unstable. Many observational and numerical studies indicate that MAULs can provide favorable conditions for MCS development (e.g., Bryan, 2005; Bryan et al., 2007; Schumacher and Johnson, 2008). The soundings are presented at the inflow region from 2000-2100 UTC with 20 min intervals in Fig. 13. The saturated lapse rate that was greater than the moist-adiabatic lapse rate was depicted in the lower layer between 900 and $700 \mathrm{hPa}$, which indicates that MAUL was established with a depth of approximately 200 $\mathrm{hPa}$ and moist absolute instability existed. It is notable that surface-based CAPE and CAPE of elevated parcels were substantially small (not shown). The profile also showed an almost (a) 850 hPa equivalent potential temperature

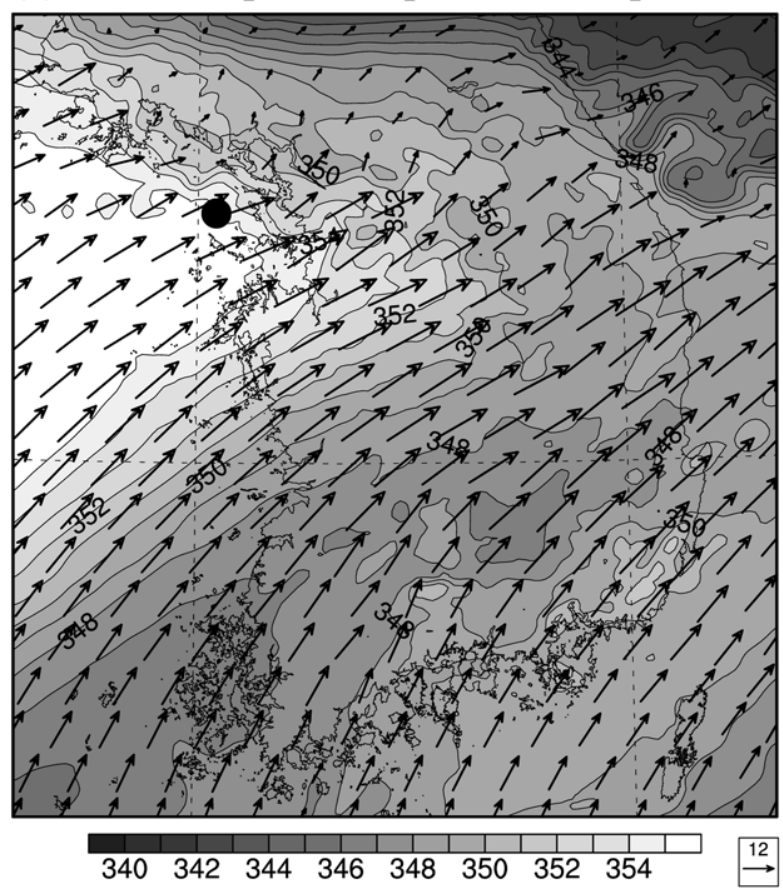

(b) 850 hPa vertical velocity

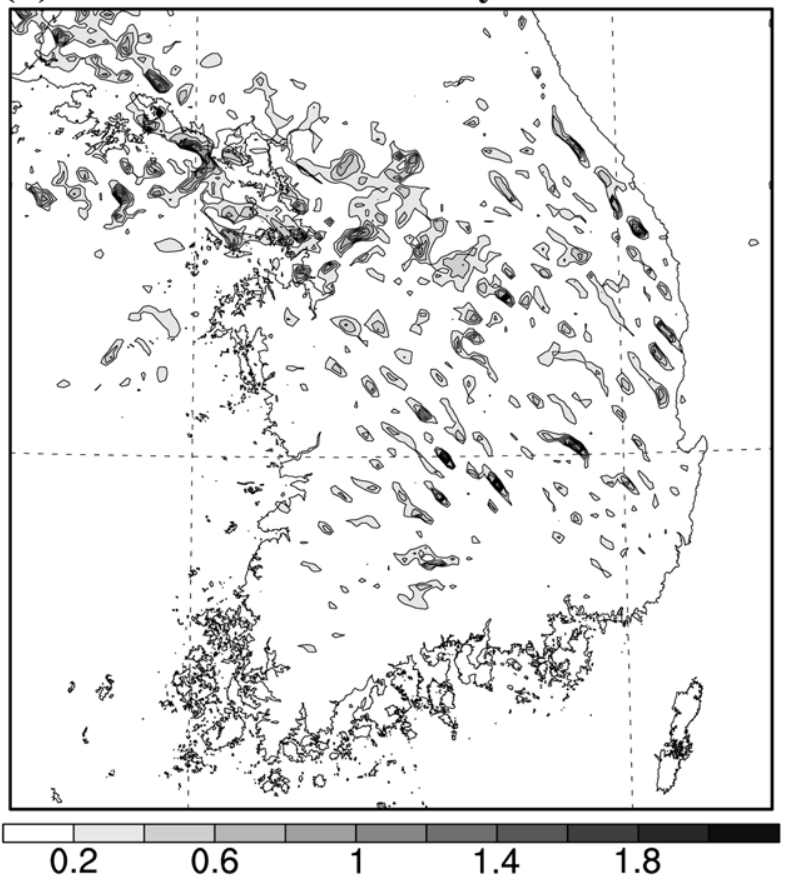

Fig. 12. Simulated (a) equivalent potential temperature (K, shaded) and wind vectors $\left(\mathrm{m} \mathrm{s}^{-1}\right)$, and (b) vertical velocity $\left(\mathrm{m} \mathrm{s}^{-1}\right.$, contour) at $850 \mathrm{hPa}$ at 2000 UTC 11 July 2006. Black dot in (a) denotes the location of the skew T - $\log \mathrm{P}$ diagram in Fig. 13.

neutral layer in lower troposphere. At low-level troposphere, MAULs were maintained in all soundings, which was similar in Bryan and Fritsch (2000). They indicated that MAULs could exist for periods greater than $30 \mathrm{~min}$ in the simulations. 

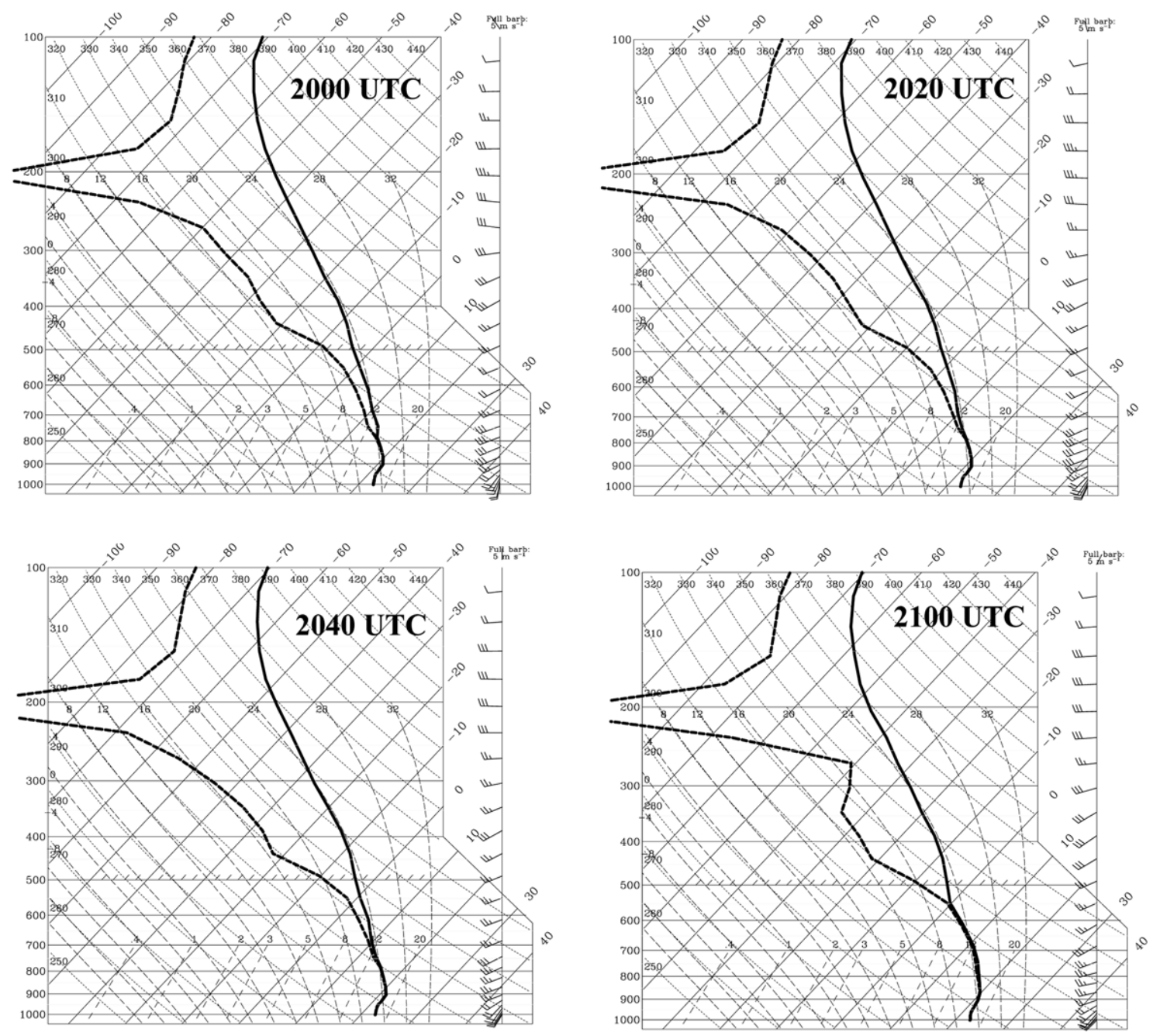

Fig. 13. Simulated skew T - $\log$ P diagram from 2000 to 2100 UTC 11 July with 20 min intervals.

In order to investigate the distribution of MAUL in this case, Fig. 14 shows the time evolution of vertical cross section from 2000-2100 UTC 11 July at 20 min intervals. The extent of MAUL was identified by a region with the cloud water mixing ratio greater than $0.1 \mathrm{~g} \mathrm{~kg}^{-1}$ and the $\theta_{\mathrm{e}}$ decreasing with height. The MAUL extended to hundreds of kilometers along the axis of the convective region of the MCS (Fig. 14a), and tens of kilometers across the convective region (Fig. 14b), which was similar to the previous study. Kain and Fritsch (1998) indicated that MAUL could extend several hundred kilometers in the horizontal. The strong ascending motion was generated at the edge of the high $\theta_{\mathrm{e}}$ inflow (Fig. 14b). The small perturbations at the edge rapidly developed into convective cells. The ascending motion transported the high equivalent potential temperature to the top of the atmosphere as each convective cell developed. The high $\theta_{\mathrm{e}}$ air was supplied from the southwest of the convective region by strong low-level jet near the $900 \mathrm{hPa}$ level. In such moist environment, the strong dynamically-driven vertical motion owing to the low level jet played a role as the source for constructing the MAUL. In the absolutely unstable layer, high $\theta_{\mathrm{e}}$ air from the base of the MAUL was mixed with low $\theta_{\mathrm{e}}$ air from the top of the MAUL. It should be noted that in this study many convective cells with vertical motion were simultaneously triggered instead of convective cells being triggered after an antecedent convective cell as shown in previous studies. Within the environment, the liner convective system in east-west direction was maintained along the elongated vertical motions.

The simulated convective cells which produced large precipitation at the rainfall peak time over Goyang were analyzed in Fig. 15. Along each convective cell, two mesoscale vortex pairs were well diagnosed with alternating positive and negative vortex tubes. At the low-level, positive and negative vortices were simulated to the rear and front of the strong updraft, respectively, and the opposite signs of the vortices were simulated at the upperlevel. These were also similar to the divergence fields along the developed updrafts. Strong convergence was dominant at the lowlevel whereas divergence was dominant at the upper-level. These are typical characteristics of developed convective cells as other studies have shown (Sun and Lee, 2002; Kim and Lee, 2006). 

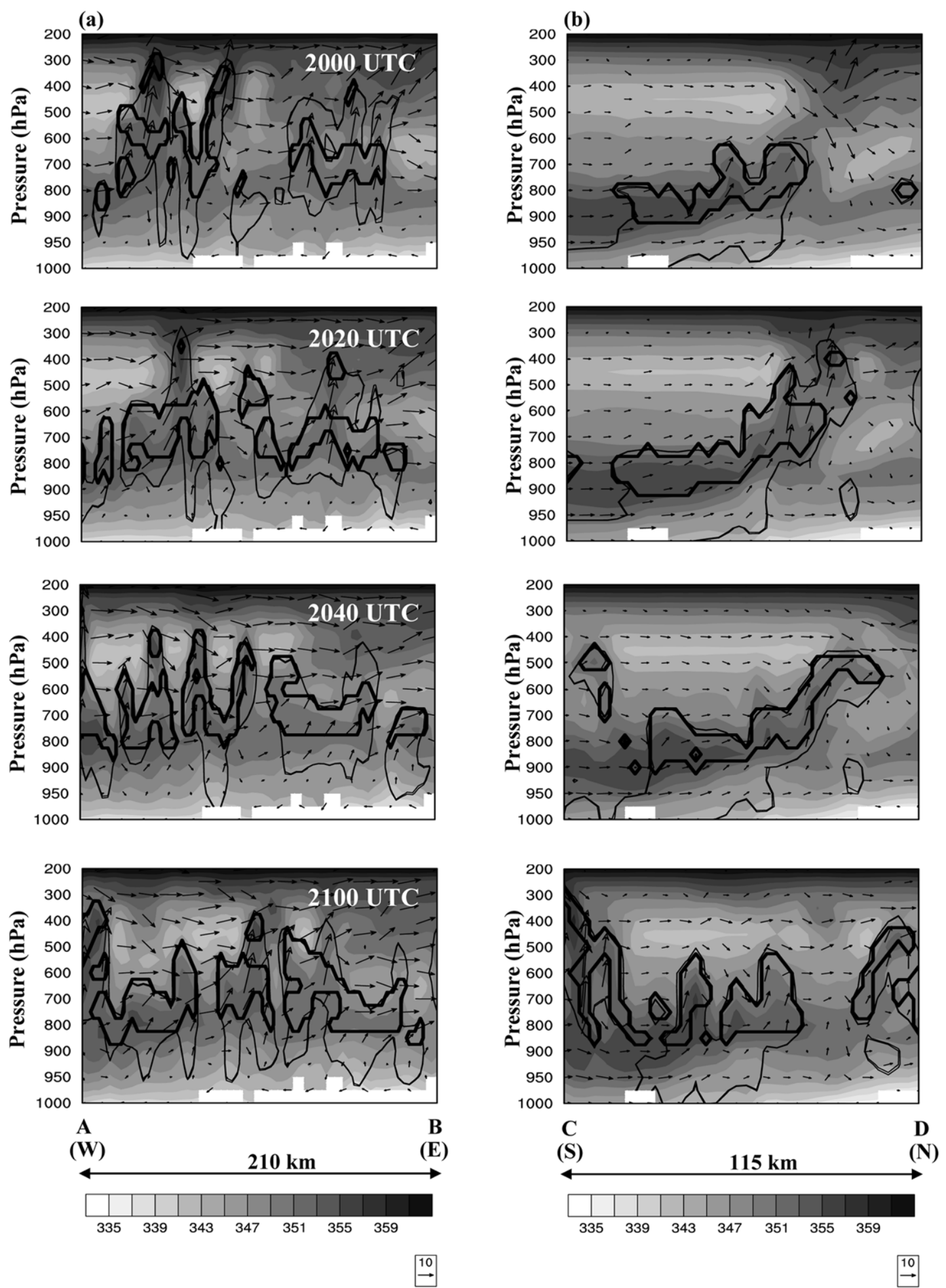

Fig. 14. (a) Vertical cross section of equivalent potential temperature (shaded), cloud water mixing ratio greater than $0.1 \mathrm{~g} \mathrm{~kg}^{-1}$ (line), MAUL (thick line) and wind vectors $\left(\mathrm{m} \mathrm{s}^{-1}\right)$ along the line A-B in Fig. 10 from 2000-2100 UTC 11 July at 20 min intervals. (b) Same as (a), except for along line C-D in Fig. 10.

\section{Conclusions and discussion}

An observational and numerical study was performed on the mesoscale convective system (MCS) responsible for heavy rainfall over the central Korean Peninsula on 12 July 2006. The synoptic chart, satellite image, and sounding data at Osan were analyzed to investigate the storm generating environment. The synthesized Doppler radar data with 1-km horizontal resolution 

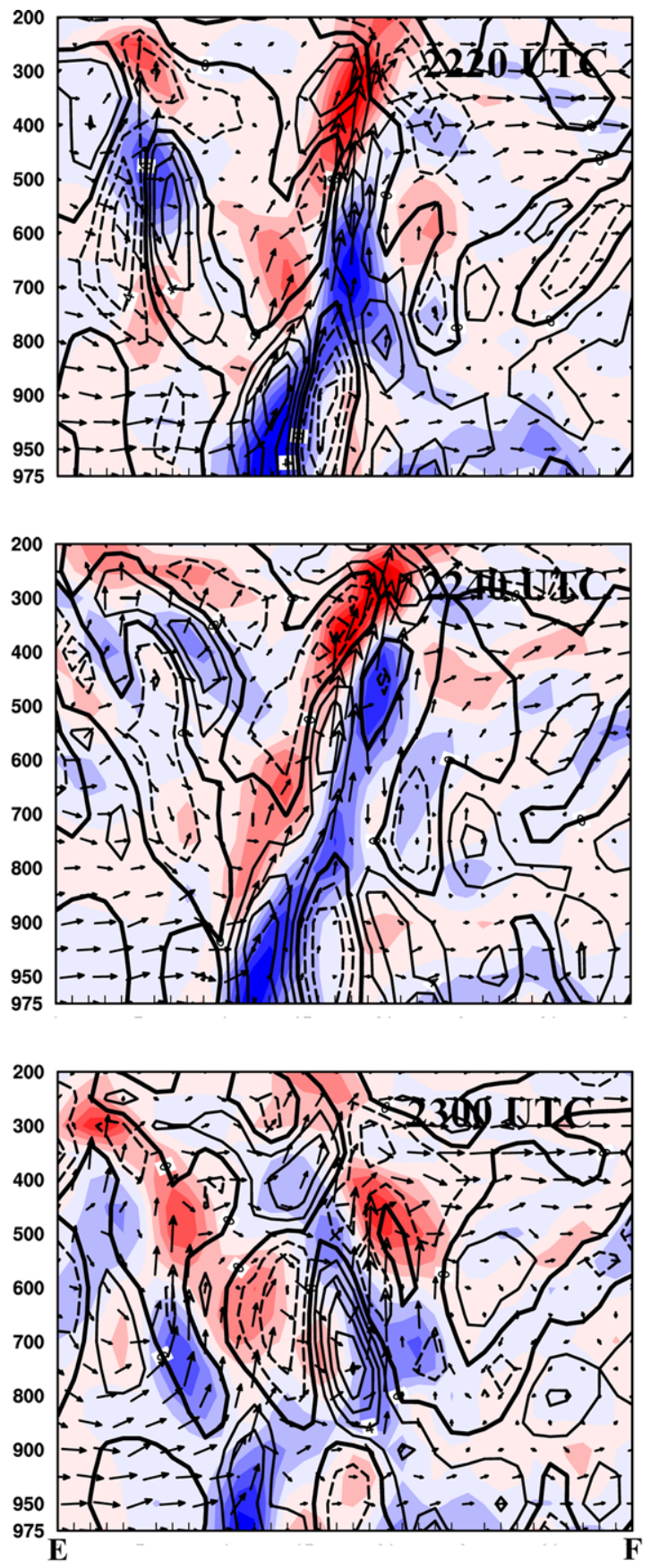

(S)

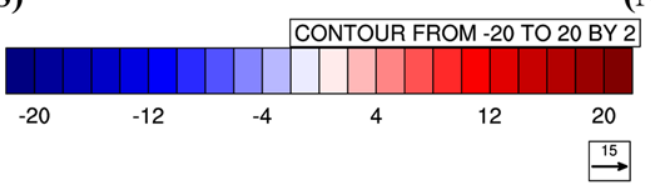

Fig. 15. Vertical cross sections of vorticity $\left(10^{-4} \mathrm{~s}^{-1}\right.$, contour), divergence $\left(10^{-4} \mathrm{~s}^{-1}\right.$, shaded $)$ and wind vectors $\left(\mathrm{m} \mathrm{s}^{-1}\right)$ along line E-F in Fig. 10 from 2220 UTC to 2300 UTC 11 July 2006 with 20 minutes intervals.

were analyzed to investigate the propagation patterns and detailed structure of the convective cells within the MCS. In addition, numerical simulations using the WRF model were performed to study the thermodynamic environment which played an important role in developing the target MCS.

In this case, warm and moist air was brought by a southwesterly low-level jet into the central Korean Peninsula from southern China. Typhoon Bilis moving to Taiwan supported lots of moisture to central Korea with a strong low-level jet. Under these environmental conditions, the target MCS was initiated at the frontal region of high equivalent potential temperature $\left(\theta_{\mathrm{e}}\right)$ near the west coast over the Yellow Sea. The ascending of the warm and moist air was induced dynamically by the LLJ. Along the ascending air, the linear convective system which was characterized by a PS archetype was initiated and developed. Within such a convective line, several convective cells evolved simultaneously. The convective cells were triggered by small thermal perturbations and abruptly developed at a verge of high $\theta_{\mathrm{e}}$ inflow. In particular, MAUL was seen at the lower troposphere with the very moist environment adding to the instability for the development of the MCS. MAULs at low-level troposphere were maintained sufficiently long enough for MCS to be initiated.

As a result, the linear MCS developed and several convective cells responsible for flash flood evolved within the MCS. In the Doppler radar data analysis, cells A and B, mainly responsible for the maximum rainfall peak in this case, developed simultaneously so that convergence inside the cells was equally strong. As the local divergence was remarkably strengthened between the two cells, the local divergence inhibited the propagation of the following convective cell (the cell B) and helped it to sustain for much longer time and to grow into a violent convective storm which produced heavy rainfall over Goyang.

Since the Korean Peninsula is exposed to the Yellow Sea and thus MCSs accompanying heavy precipitation over Korea usually initiate near the west coastal area over the Yellow Sea, a conventional parcel theory which is based on surface-based buoyancy can not be applicable for the explanation of storm development. Thus, in future studies, the dynamics of topography and the convergence of surface friction, over the coastal region, should be investigated. Even though most concepts applied in this study originated from studies of MCS cases in North America, it can be also tied to some MCS cases over the Korean Peninsula. The development of convective cells in the MCS in this study leads to the possible explanation of heavy rainfall over the Korean Peninsula with low CAPE case. However, for robust results more cases for longer time periods are needed in the future.

Acknowledgements. This research was supported by International S\&T Cooperation Program through the National Research Foundation of Korea (NRF) funded by the Ministry of Education, Science and Technology (MEST) (2010-00715), and the Korea Meteorological Administration Research and Development Program under Grant RACS 2010-2016. This research was also supported by the BK21 program of the Korean Government Ministry of Education. 


\section{REFERENCES}

Bluestein H. B., and M. H. Jain, 1985: Formation of mesoscale lines of precipitation: severe squall lines in Oklahoma during the spring. $J$. Atmos. Sci., 42, 1711-1732.

Bryan, G. H., 2005: Spurious convective organization in simulated squall lines owing to moist absolutely unstable layers. Mon. Wea. Rev., 133, 1978-1997.

, and J. M. Fritsch, 2000: Moist absolute instability: The sixth static stability state. Bull. Amer. Meteor. Soc. 81, 1207-1230.

, R. Rotunno and J. M. Fritsch, 2007: Roll circulations in the convective region of a simulated squall line. J. Atmos. Sci., 64, 12491266.

Dudhia, J., 1996: A multi-layer soil temperature model for MM5. Preprints, The Sixth PSU/NCAR Mesoscale Model Users' Workshop, Boulder, Colorado, 49-50.

Evans, J. S., and C. A. Doswell III, 2001: Examination of derecho environments using proximity soundings. Wea. Forecasting, 16, 329342 .

Gao, J., M. Xue, A. Shapiro, and K. K. Droegemeier, 1999: A variation method for the analysis of three-dimensional wind fields from two Doppler radars. Mon. Wea. Rev., 127, 2128-2142.

Hong, S.-Y., J. Dudhia, and S.-H. Chen, 2004: A revised approach to ice microphysical processes for the bulk parameterization of clouds and precipitation. Mon. Wea. Rev., 132, 103-120.

, Y. Noh, and J. Dudhia, 2006: A new vertical diffusion package with an explicit treatment of entrainment processes. Mon. Wea. Rev., 134, 2318-2341.

Kain, J. S., 2004: The Kain-Fritsch convective parameterization: An update. J. Appl. Meteorol, 43, 170-181.

, and J. M. Fritsch, 1990: A one-dimensional entraining/detraining plume model and its application in convective parameterization. $J$. Atmos. Sci., 47, 2748-2802.

, and 1993: Convective parameterization for mesoscale models: The Kain-Frisch scheme, The Representation of Cumulus Convection in Numerical Models, Meteorol, Monogr. Ser., vol. 24, edited by K. A. Emanuel and D. J. Raymond, Amer. Meteor. Soc., 165170.

and 1998: Multiscale convective overturning in mes-

oscale convective systems: Reconciling observations, simulations, and theory. Mon. Wea. Rev., 126, 2254-2273.

Kim, H. W. and D. K. Lee, 2006: An observational study of mesoscale convective systems with heavy rainfall over the Korean Peninsula. Wea. Forecasting, 21, 125-148.

Lee, D. K., H. R. Kim, and S. Y. Hong, 1998: Heavy rainfall over Korea during 1980-1990. Korean J. Atmos. Sci., 1, 32-50.

Liu, Y., A. Bourgeois, T. Warner, S. Swerdlin, and J. Hacker, 2005: An implementation of obs-nudging-based FDDA into WRF for supporting ATEC test operations. 2005 WRF user workshop. Paper 10.7

National Emergency Management Agency : 2009, Disaster yearbook, Korea, 755 pp.

Park, S. G., and D. K. Lee, 2009: Retrieval of high-resolution wind fields over southern Korean Peninsula using Doppler weather radar network. Wea. Forecasting, 24, 87-103.

Parker, M. D., 2007: Simulated convective lines with parallel stratiform precipitation. Part I: An Archetype for Convection in Along-Line Shear. J. Atmos. Sci., 64, 267-288.

and R. H. Johnson, 2000: Organizational modes of midlatitude mesoscale convective systems. Mon. Wea. Rev., 128, 3413-3436.

Rinehart, R. E., 1997: Radar for meteorologists. Rinehart Publications, 3rd ed., 166-167.

Schumacher, R. S., and R. H. Johnson, 2006: WRF model simulations of a quasi-stationary, extreme-rain-producing mesoscale convective system. 2006 WRF user workshop. Paper 2.4 and 2008: Mesoscale processes contributing to extreme rainfall in a midlatitude warm-season flash flood. Mon. Wea. Rev., 136 3964-3986.

Skamarock, W. C., J. B. Klemp, J. Dudhia, D. O. Gill, D. M. Barker, W. Wang, and J. G. Powers, 2005: A description of the Advanced Research WRF version 2, NCAR Tech. Note NCAR TN-468+STR.

Sun J., and T. Y. Lee, 2002: A numerical study of an intense quasistationary convection band over the Korean Peninsula. J. Meteor. Soc. Japan, 80, 1221-1245.

Wee, T. K., 1999: A cumulus parameterization based on cloud resolving simulations of mesoscale convective systems (in Korean). Ph.D. thesis, Seoul National University, 308 pp.

Yu, W., Y. Liu and T. Warner, 2007: An evaluation of 3dvar, nudgingbased fdda and a hybrid scheme for summer convection forecast using WRF-ARW model. 2007 WRF user workshop. Paper 2.4. 